\title{
COMMENTARY
}

\section{Whole blood thromboelastometry: another Knight at the Roundtable?}

\author{
Martin H Bluth' and Jeffry L Kashuk ${ }^{2 *}$ \\ See related research by Schöchl et al., http://ccforum.com/content/15/6/R265
}

\begin{abstract}
Thromboelastography and thromboelastometry represent viscoelastic diagnostic methodologies with promising application to diseases of altered coagulation. Their use in trauma-induced coagulopathy as a means of assessing the real-time status of the patient's functional coagulation profile in addition to its impact on effective and appropriate use of blood product support has been gaining acceptance among trauma surgeons, anesthesiologists, and transfusion medicine specialists. However, the ability of viscoelastic testing to augment or supplant conventional coagulation testing for the diagnosis and management of trauma-induced coagulopathy remains controversial. Many of these issues pertain to the differences in methodology, instrumentation, logic, accessibility, ease of use, operator variability, and the method's relationship to patient care, blood product use, cost, and conventional testing algorithms.
\end{abstract}

In the 14th-century alliterative poem Sir Gawain and the Green Knight, the Green Knight seeks to best King Arthur and his court in a game. The Green Knight says that he will allow whomever accepts the challenge to strike him with his own axe, on the condition that the challenger find him in exactly 1 year to receive a blow in return. Sir Gawain, the ostensibly least fitting of the Knights of the Round Table, leaps to take on the challenge himself and provide honor to his King. In many respects, the valiancy of emerging diagnostics is put to a similar test as reported in the present issue by Schöchl and colleagues [1].

*Correspondence: jeffrykashuk@gmail.com

2Department of Trauma, Surgical Critical Care and Acute Care Surgery, St. Mary's of Michigan and Midwestern Surgical Associates, 999 Washington \#2, Saginaw, MI 48602, USA

Full list of author information is available at the end of the article
Trauma-induced coagulopathy (TIC) has been identified early after patient presentation [2], is associated with shock and massive transfusion (MT) requirements, may occur in the absence of coagulation factor depletion [3], and has been reported to complicate up to $30 \%$ of major trauma admissions [4]. Accordingly, early and accurate diagnosis of TIC is essential to facilitate and optimize rapid provision of appropriate blood products in order to decrease morbidity and mortality, to promote efficient utilization of valuable resources, and to avoid wastage of nonessential therapy.

Conventional coagulation testing (CCT) remains the predominant method of assessing coagulation status worldwide, including the prothrombin time, activated partial thromboplastin time, platelet tests, and fibrinogen concentration. Despite this predominance, these tests have never been proven accurate in the hemorrhaging trauma patient [5] and suffer from a prolonged laboratory turnaround time of 1 hour or more in certain settings [6]. Finally, since they are plasma based, the assays do not accurately reflect the physiological milieu of whole blood, where multiple elements - including endothelium, platelet interactions, and subsequent thrombin generation - contribute to ultimate clot strength, leading to a meticulous balance of hemostasis and lysis. Accordingly, there has been recent growing enthusiasm for alternate methods of coagulation assessment.

Thromboelastography (TEG'; the name is a trademark of Haemoscope Corp. USA) and thromboelastometry $\left(\right.$ ROTEM $^{\circ}$; the name is a trademark of Tem Innovations $\mathrm{GmbH}$, Munich, Germany) tests that assess the viscoelastic properties of whole blood are relatively newer members of the diagnostic armamentarium currently under investigation for the assessment of patients at risk for TIC $[7,8]$. Both tests provide the potential to supersede CCT in the diagnosis of TIC because they provide real-time assessment of clot physiology from initial activation, subsequent achievement of tensile strength, and eventual resolution/degradation via a graphical tracing of fibrin polymerization and clot strength. Beyond the early diagnosis of TIC via point-of-care assessment, perhaps the most promising future for $\mathrm{TEG}^{\circ} /$ 
ROTEM $^{\circ}$ technology is the additional potential benefit of early goal-directed therapy, with the objective to optimize and possibly reduce blood product utilization [9].

In the present issue of Critical Care, Schöchl and colleagues evaluated whole blood ROTEM $^{\circ}$ assays and the test's ability to predict those seriously injured patients (all with Injury Severity Score $>16$ ) likely to require MT ( $>10$ units red blood cells/24 hours) during the subsequent hospitalization [1]. Utilizing a variety of assays (extrinsically activated assay with tissue factor, intrinsically activated assay using ellagic acid, and fibrin-based extrinsically activated assay with tissue factor and the platelet inhibitor cytochalastin D), the authors assessed the clotting time, clot formation time, clot amplitude at the end of the clotting time, and maximum clotting firmness, and compared the predictive value of these tests with CCT and other physiologic parameters. Although Schöchl and colleagues noted that the best predictive tests for MT were a simple hemoglobin or Quick value, they observed that the predictive values of the clot amplitude at the end of the clotting time and the maximum clotting firmness for the fibrin-based extrinsically activated assay with tissue factor and the platelet inhibitor cytochalastin D were similar, with the chief advantage being the availability of results within 10 minutes.

At first glance, the astute clinician may argue that severely injured patients at risk for TIC can already be identified via CCT or clinical factors, such as a variety of scoring systems $[10,11]$, and hence why the need for another potentially expensive test to provide the same information albeit somewhat earlier? Accordingly, as with many excellent studies, the fine details raise more questions than provide answers. As pointed out by the authors, the rapid availability of point-of-care whole blood assays affords a much more comprehensive assessment of the true relational hemostatic state of the individual patient. For instance, hyperfibrinolysis - which has recently been described by several investigators in the trauma setting [12-14] and can only be rapidly identified via viscoelastic tests - was clearly noted in 19 patients. Furthermore, the mean fibrinogen level in the MT group was $95 \mathrm{mg} / \mathrm{dl}$. Given the emerging significance of hyperfibrinolysis in the pathophysiology of TIC [12], and the current use of fibrinogen concentrates for resuscitation in European centers, it would be interesting for the authors to correlate the frequency of this phenomenon in the MT group and its association with the fibrinogen level and clot strength. Furthermore, recent evidence supporting early use of antifibrinolytics [15] has prompted many centers to now include such therapy as a first-line adjunct to their MT protocols.

Schöchl and colleagues are to be congratulated for this important work, and we agree that current evidence continues to grow in support of point-of-care viscoelastic analysis of coagulation status. Of note, however, the application and adaption of this technology present significant challenges. For instance, it should be noted that the authors' group have been working with these techniques for some time, and have no doubt moved beyond a significant learning curve for use of these techniques. Furthermore, recognizing the complex interactions of the hemostatic system, we posit that that TEG ${ }^{\circ}$ ROTEM $^{\circ}$ should be considered as a tool to better appreciate relational hemostatic mechanisms that probably coexist in TIC. While we agree with the authors that $\mathrm{ROTEM}^{\circ} \mathrm{can}$ afford the clinician/surgeon a rapid diagnosis of TIC, it must be noted that ROTEM ${ }^{\circ}$-based assessments were similar to CCT when only simply applied for predicting MT.

In sum, the authors have clearly shown that $\mathrm{TEG}^{\circ} \%$ ROTEM $^{\circ}$ holds promise as an important tool for the rapid diagnosis of TIC. We encourage the authors to continue their investigations, moving beyond observational trials to therapeutic interventions, utilizing this technology to improve our understanding of the complex physiologic changes to the coagulation system induced by significant injury. Such progress will firmly establish viscoelastic analyses as a notable and valiant member of the diagnostic roundtable.

\section{Abbreviations}

CCT, conventional coagulation testing; MT, massive transfusion; TEG, thromboelastography; TIC, trauma-induced coagulopathy.

\section{Competing interests}

The authors declare that they have no competing interests.

\section{Author details}

'Department of Pathology, Division of Transfusion Medicine, Detroit Medical Center, Detroit, MI 48034, USA. ${ }^{2}$ Department of Trauma, Surgical Critical Care and Acute Care Surgery, St. Mary's of Michigan and Midwestern Surgical Associates, 999 Washington \#2, Saginaw, MI 48602, USA.

\section{Published: 22 December 2011}

\section{References}

1. Schöchl H, Cotton B, Inaba K, Nienaber U, Fischer H, Voelckel W, Solomon C: FIBTEM provides early prediction of massive transfusion in trauma. Crit Care 2011, 15:R265.

2. Brohi K, Cohen MJ, Ganter MT, Schultz MJ, Levi M, Mackersie RC, Pittet JF: Acute coagulopathy of trauma: hypoperfusion induces systemic anticoagulation and hyperfibrinolysis. J Trauma 2008, 64:1211-1217.

3. Brohi K, Cohen MJ, Ganter MT, Matthay MA, Mackersie RC, Pittet JF: Acute traumatic coagulopathy: initiated by hypoperfusion: modulated through the protein C pathway? Ann Surg 2007, 245:812-818.

4. MacLeod JB, Lynn M, McKenney MG, Cohn SM, Murtha M: Early coagulopathy predicts mortality in trauma. J Trauma 2003, 55:39-44

5. Spahn DR, Rossaint R: Coagulopathy and blood component transfusion in trauma. Br J Anaesth 2005, 95:130-139.

6. Toulon P, Ozier Y, Ankri A, Fleron MH, Leroux G, Samama CM: Point-of-care versus central laboratory coagulation testing during haemorrhagic surgery. A multicenter study. Thromb Haemost 2009, 101:394-401.

7. Luddington RJ: Thrombelastography/thromboelastometry [review]. Clin Lab Haematol 2005, 27:81-90.

8. Afshari A, Wikkelsø A, Brok J, Møller AM, Wetterslev J: Thrombelastography (TEG ${ }^{\circledR}$ ) or thromboelastometry $\left(\mathrm{ROTEM}^{\circledR}\right)$ to monitor haemotherapy versus usual care in patients with massive transfusion [review]. Cochrane Database Syst Rev 2011, 3:CD007871. 
9. Kashuk JL, Moore EE, Sawyer M, Le T, Johnson J, Biffl WL, Cothren CC, Barnett C, Stahel P, Sillman CC, Sauaia A, Banerjee A: Postinjury coagulopathy management: goal directed resuscitation via POC thrombelastography. Ann Surg 2010, 251:604-614.

10. Cotton BA, Dossett LA, Haut ER, Shafi S, Nunez TC, Au BK, Zaydfudim V, Johnston M, Arbogast P, Young PP: Multicenter validation of a simplified score to predict massive transfusion in trauma. J Trauma 2010, 69(Suppl 1):S33-S39.

11. Nunez TC, Voskresensky IV, Dossett LA, Shinall R, Dutton WD, Cotton BA: Early prediction of massive transfusion in trauma: simple as ABC (assessment of blood consumption)? J Trauma 2009, 66:346-352.

12. Kashuk JL, Moore EE, Sawyer M, Wohlauer M, Pezold M, Barnett C, Biffl WL, Burlew CC, Johnson JL, Sauaia A: Primary fibrinolysis is integral in the pathogenesis of the acute coagulopathy of trauma. Ann Surg 2010, 252:434-442.

13. Schochl H, Frietsch T, Pavelka M, Jambor C: Hyperfibrinolysis after major trauma: differential diagnosis of lysis patterns and prognostic value of thrombelastometry. J Trauma 2009, 67:125-131.
14. Theusinger OM, Wanner GA, Emmert MY, Billeter A, Eismon J, Seifert B, Simmen HP, Spahn DR, Baulig W: Hyperfibrinolysis diagnosed by rotational thromboelastometry $\left(\mathrm{ROTEM}^{\bullet}\right)$ is associated with higher mortality in patients with severe trauma. Anesth Analg 2011, 113:1003-1012.

15. CRASH-2 Collaborators; Roberts I, Shakur H, Afolabi A, Brohi K, Coats T, Dewan Y, Gando S, Guyatt G, Hunt BJ, Morales C, Perel P, Prieto-Merino D, Woolley T: The importance of early treatment with tranexamic acid in bleeding trauma patients: an exploratory analysis of the CRASH-2 randomised controlled trial. Lancet 2011, 377:1096-1101.

doi:10.1186/cc10569

Cite this article as: Bluth MH, Kashuk JL: Whole blood thromboelastometry: another Knight at the Roundtable? Critical Care 2011, 15:1021. 